Society for the Anthropology of Work • Policing and Labor

\title{
The (Antifascist) Police Officer as Worker: Futurizing the Present
}

Susana Durão, Wellynton Samuel Oliveira de Souza

Published on: Dec 01, 2020

DOI: $10.21428 / 1 \mathrm{~d} 6$ be30e.f4f827ae

License: Creative Commons Attribution 4.0 International License (CC-BY 4.0). 
In July 2020, it was reported that Brazil's Ministry of Justice and Public Security had compiled an intelligence report on the country's Antifascist Police Officers Movement (APOM). APOM is a national network mostly constituted of civilian and military police, but also representing all sorts of security forces who intend to participate in Brazil's political life. Its aim is to reform the field of law enforcement and understandings about public security in Brazil. The core idea of the movement is the (re)construction of the police officer as a worker. Based on extensive document and media analysis and also in-depth interviews with APOM members, this text aims to better understand why the movement considers itself to be reinventing the notion of policing as work.

Accused of terrorism upon the release of its "Antifascist Policemen in Defense of Popular Democracy” manifesto, APOM became the object of scrutiny by the right-wing government of President Jair Bolsonaro. But in August 2020, the Federal Supreme Court suspended these operations and placed limits on the government's intelligence gathering activities. Meanwhile, after reactions to the killing of George Floyd in the United States went viral, dissent about who has the right to call themselves antifascist broke out in Brazil. Mark Bray, author of the anarchist manifesto Antifa (Bray 2017), criticized Leonel Radde, a well-known and media-friendly Brazilian police officer, after the latter appeared in a video holding the book and thanking the publisher for sending it to him. Bray tweeted "No no no no no ... If you're really an antifascist then quit your job," to which Radde replied (authors' translation):

The police worker that investigates Marielle Franco's murder, ${ }^{1}$ is he a fascist? The policeman that investigates deaths in the periphery, cases of racism, or violence against women, is he a fascist? Policemen that mobilize in the defense of democracy, shouldn't they have some backing and respect? Is the whole institution fascist? If we want to better our country's situation, we'll have to count on the police.

In Brazil, police participation in political life is mostly aligned with the conservative wing and is often associated with the Bancada da Bala (Bullet Caucus) ${ }^{2}$ as well as the Military and Evangelical Caucuses (Berlatto, Codato, and Bolognesi 2016). But earlier this year, APOM started to show up on social media, gaining a visibility never before seen by a group of police officers. They have captivated intellectuals and politicians from left-wing parties that are organizing_pluralist slates for the next election. As a growing political force, APOM has also appeared on the radar of a government that treats its opponents as enemies to be slaughtered (Nobre 2020). Still, as the 
controversy between Bray and Radde shows, APOM has not escaped the public mistrust that structures a view of police as violence workers (Huggins, HaritosFatouros, and Zimbardo 2002; Seigel 2018).

\section{The Police Officer as Worker}

When APOM published its founding manifesto in 2017, they pronounced:

Police officers must be built like workers! The recognition of the right to strike, of free association, of free party affiliation, as well as the end of administrative prisons, are milestones in this fight against the condition of sub-citizenship to which many police officers are subjected. We believe that this is the only way in which police officers can come to recognize themselves in the struggle of the other workers, being then recognized by the whole working class as brothers in the antifascist struggle.

APOM members believe the only way to change violent behavior among police is to affirm that policing is labor and that, as workers, officers feel as vulnerable and precarious as other categories of workers. The recognition of a common vulnerability among a working class of which police form a part is more than a question of class solidarity; it is seen as a way to defeat a common misperception that exalts the violent supra-citizen aspects of policing. As one of the founders of APOM has said: "To build a working policeman is to build a new model of police, to produce a new police officer."

It is the notion of the policeman as a worker with an individual ethic capable of embracing a project for the transformation of policing that is at the center of the controversies surrounding the members of APOM. In line with the proposed Constitutional Amendment 51, the movement points out the need to reform police institutions according to four major principles: a clear distinction between the police and the army; equal opportunities for career progression; a "one cycle" system that enables each police force to perform all police tasks; and promotion of transparency, accountability, external control, and respect for human rights.

Positioning the police officer as a worker challenges the very model of society embraced by the extreme-right groups in power today. The government's rhetoric tends to be grounded in the idea of an officer who fights and dies for the homeland, thereby implicitly linking him to military and conservative values. Yet the candidates that APOM is backing in the November 2020 municipal election complicate this narrative in that they include at least twenty police officers, who are linked to different parties from the center to the left and who identify themselves as the Bancada Anti- 
Bala (Anti-Bullet Caucus) -in clear reference to their right-wing counterparts. By seeking to reform public security and other agendas, these officers enter the heart of the political game and constitute themselves as a threat to the conservative status quo of the Brazilian police and the national government itself.

\section{Where Do Antifascist Police Officers Come From?}

The heterodox position of the APOM is related to some members' participation in professional associations, police groups against mass incarceration and for drug liberalization, as well as LGBT, feminist, and antiracism groups. It is worth mentioning that a tradition of police dissent dates back to the period of the military dictatorship from 1964 to 1985 (Vasconcelos 2006). More recently, though, police officers have benefited from the investment made by previous governments in public security graduate and postgraduate training (Pinto et al. 2014). As they enter these academic settings, many officers became familiar with sociological jargon and with legal and criminological criticism.

Inspired by Michel Foucault's preface to Gilles Deleuze and Félix Guattari's (1983) classic Anti-Oedipus, APOM defines fascism not merely as a state form but as a "way of life" that has been taking shape in Brazil since before Bolsonaro's election. APOM members also make a distinction between antifascism and antifascists, insisting that their position is not against persons but rather ideas and ideals. As Pedro Chaves, a police officer from Rio Grande do Norte who is also known as Chê, declared:

Our antifascism was born before Bolsonaro. It is against what happens in institutions-just see how things work within the military police-but also outside, on the outskirts, in the war on drugs, in the relationship between police and youth. Our antifascism is not against Bolsonaro, but he was the one who allied himself with fascism, so he is an element of aversion.

Until Bolsonaro's election, there was no organized discourse in Brazil related to antifascism. Political authoritarianism, police violence, the reproduction of racial and class inequality by police violence: none of these topics was treated in the context of fascism, but was rather viewed as "militaristic" in a broad sense. APOM was a pioneer in redefining the terms of the debate, offering another look at what was happening in the country, stimulating the debate around public security and the need for a new police. After them, other groups began to appear in public calling themselves antifa.

APOM members consider fascism as an embedded social and institutional perspective based on the War on Drugs, as the main policing trend in Brazil. Violence is seen as a 
way to solve social problems, even if that means exterminating part of the poorer black population. Statistics show that black people comprise $\underline{75.4}$ percent of those killed by the police. According to APOM, the substance of fascism is not produced from the top down; rather, it can be identified in the norms and beliefs of citizens when exalting the notion of the police officer as a patriotic warrior that saves the nation from the immorality of crime. APOM members acknowledge that these values have started to appear inside the police forces, but see them as a signal of a wider trend in society. Transforming this warlike hero into a worker puts police officers in an alternative antifascist position.

\section{A New Police Identity for the Future}

APOM members invite each Brazilian police officer to consider themselves, and by extension to be considered, a member of a wider work community. They argue for rebooting the very idea of police in Brazil. How can we square that critical proposition with classic Euro-American theories that define the institutionalization of police work as a historical achievement? We might say that APOM, in a very original way, contests the colonization of thought about policing in Brazil, a colonization effected by elites but often reproduced by officers themselves. In that sense, we agree with Beatrice Jauregui (2018, forthcoming) when she states that police worker politics and their legitimacy in the global South are co-configured with processes of democratization, decolonization, and development, and that despite local specificities police worker politics is a global form.

In the Brazilian case, the police officer as a worker is a utopian rather than historical construction or prognosis (Bayley and Shearing 1996). As this political struggle is staged in the everyday arena of street patrols, APOM members come to see themselves as "future-makers" (see Appadurai 2013). The antifascist officers we have come to know in our research stand for the recognition of the plurality of police identity that they infuse into their own organizations. Orlando Zaccone is not merely a delegado of the civil police of Rio de Janeiro; he is a Hare Krishna, skateboarder, and advocate for drug liberalization, and he has a PhD in political science. Denilson Neves is a civil police investigator, but at other points in his life he participated in the students' movement and was a union leader at the Bahia Petrochemical Complex. Anderson Duarte is a captain in the military police of Ceará, grew up in a shantytown, and completed studies in geography and education. Páris Borges is a trans woman and federal highway police officer; she fights for the trans cause while working toward a Master's in law and sociology. 
"From the very beginning, our goal was to build up the policeman as a worker. But this is a long-term project; we are clear about that," said Dalchem Viana on a YouTube livestream in August 2019. According to APOM members, the political and social construction of the police officer as a worker is a step that is needed to get those workers participating as citizens in the democratic process. As in Radde's reply to Bray, to improve Brazil the police cannot be left out. The police work of the future must correct the mistakes of the past and establish democratic freedom within and outside the police force. In the end, such a movement is against fascism insofar as it is built in a world where the extreme right has come to power.

\section{Notes}

1. Marielle Franco was a politician and human rights activist whose killing in 2018 was linked to government officials.

2. The Bullet Caucus is a right-wing and liberal coalition of politicians who defend civil armament and the loosening of rules concerning the trade and acquisition of small arms.

\section{Author Bios}

Susana Durão is Adjunct Professor of Anthropology at the State University of Campinas/UNICAMP and Senior Research Fellow at the Maria Sibylla Merian Centre Conviviality-Inequality in Latin America, an academic consortium that aims to promote interdisciplinary cooperation among scholars from Germany, Latin America, the Caribbean, and other regions of the world.

Wellynton Samuel Oliveira de Souza is an undergraduate studying social sciences at the State University of Campinas/UNICAMP.

\section{Preview Image}

Photo by $\underline{\text { Chris Henry. }}$

\section{References}

Appadurai, Arjun. 2013. The Future as Cultural Fact. Essays on the Global Condition. New York: Verso.

Bayley, David, and Clifford Shearing. 1996. “The Future of Policing." Law and Society Review 30(3): 585-606. 
Berlatto, Fábia, Adriano Codato, and Bruno Bolognesi. 2016. “From Police to Politics: Analyzing the Profile of Candidates from the State's Repressive Forces to the Chamber of Deputies." Revista Brasileira de ciência política 21: 79-122.

Bray, Mark. 2017. Antifa: The Anti-Fascist Handbook. New York: Melville House.

Deleuze, Gilles, and Félix Guattari. 1983. Anti-Oedipus: Capitalism and Schizophrenia. Minneapolis: University of Minnesota Press. Originally published in 1972.

Huggins, Martha K., Mika Haritos-Fatouros, and Philip G. Zimbardo. 2002. Violence Workers: Police Torturers and Murderers Reconstruct Brazilian Atrocities. Berkeley: University of California Press.

Jauregui, Beatrice. 2018. "Police Unions and the Politics of Democratic Security and Order in Postcolonial India." Qualitative Sociology (41): 145-72.

. Forthcoming. "Police Worker Politics in India and Beyond." Global and Comparative Policing Review.

Nobre, Marcos. 2020. Ponto final: A guerra de Bolsonaro contra a democracia. São Paulo: Editora Todavia.

Pinto, Nalayne Mendonça, Haydée Caruso, Luciane Patrício, Elizabete Ribeiro Albernaz, and Vanessa de Amorin Cortes. 2014. “ursos de pós-graduação em segurança pública e a construção da Renaesp como política pública: considerações sobre seus efeitos a partir de diferentes olhares." In Pensando a segurança pública, volume 4: Avaliações, diagnósticos e análises de ações, programas e projetos em segurança pública, edited by Cristiane do Socorro Loureiro Lima and Gustavo Camilo Baptista e Isabel Seixas de Figueiredo, 225-59. Brasília: Ministério da Justiça.

Seigel, Micol. 2018. Violence Work: State Power and the Limits of Police. Durham, NC: Duke University Press.

Vasconcelos, Cláudio Bezerra de. 2006. “ㅆ política repressiva contra militares no Brasil após o golpe de 1964.” Locus: Revista de história 12(2): 155-66. 